\title{
A STUDY OF RHYTHM IN PRIMITIVE MUSIC'.
}

\author{
BY CHARLES S. MYERS, \\ Gonville and Caius College, Cambridge.
}

I. Peculiarities of rhythm in the music of the Malays of Sarawak. 1. Description of their orchestra. 2. The method experimentally employed to record the rhythm. 3. Analysis of the records.

II. Further evidence of rhythmical complications in primitive music. 1. Analogy of the above records with the rhythm of early Indian music and with Greek metre. 2. The use of simultaneous contrary rhythms. 3. The use of frequently changing rhythms.

III. The place of rhythm in primitive and advanced music.

I.

1. During a visit to Borneo I had the opportunity of investigating some exceptionally complicated methods of gong-beating which are in vogue among the Sarawak Malays.

Their orchestra usually consists of (1) a set of seven or eight small gongs or kranang of different pitch, which are arranged before the player in horizontal series upon a frame of bamboo and rattan, (2) a large gong or chanang, (3) two small drums or gendang, and (4) a still larger gong, the tawak or tetáwak. The kranang, chanang and gendang always keep excellent time with one another. The gongs of the kranang are rapidly sounded, about six per second. The chanang emits a high note and regularly accentuates the first of every four sounds of the kranang. The two gendang are called 'mother' and 'child.' When one of them is silent, the other is beaten; together, their rhythm supports that of the kranang, the accented beat coinciding with that of the chanang.

1 A paper communicated to the Psychological Society on April 1st, 1905. 
On the other hand, the tawak, a large gong of about sixty centimetres in diameter, is played in a rhythm seemingly quite independent of that of the other instruments of the orchestra. It may be beaten in various modes, but they are alike characterized by a complete absence of time, so far as can be appreciated by the European ear. The accented beats appear to recur with incomprehensible irregularity. I remember that on one occasion the player of the tawal becoming tired, he passed on the instrument to another Malay who proceeded to beat it just as a European would do, keeping strict time with the orchestra. He was laughed at by his audience and very soon retired covered with ridicule. It was evident that only an expert could play it.

No movement of the lips or feet accompanies this curious rhythm. It is listened to without singing or dancing. The unaccented beats of the tawak are damped by the fingers of the player's left hand. His right hand at one time beats the body, at another the raised central boss of the instrument. The tawak is also used by the Kenyahs and other peoples of Sarawak to carry news of death, war, childbirth, etc., to neighbouring villages, each mode of beating having a recognized meaning ${ }^{1}$.

2. I endeavoured to investigate the peculiar methods of sounding the tawak in the above orchestra by allowing a Malay to tap upon a Morse key just as if he were beating the tawak, while the other instruments were being played as usual. The taps thus made were recorded upon the travelling surface of a smoked drum by means of an electrically driven time-signal. Below the time-signal a clock recorded intervals of a fifth of a second on the smoked surface. In this way I was able to obtain a record of the number of tenths of seconds which elapsed between successive beats of the tawak. I hoped that a leisured visual study of these intervals would lead to an understanding of this curious performance which to the European ear appeared so completely devoid of system, defying every attempt at rhythmization.

3. The Malay who thus recorded the sounds of the tawak told me that there were many methods of beating it. I have records of four different methods and I present them here. Unfortunately my attention was confined too exclusively to the recording apparatus to allow me to take note of the position of the accented beats ${ }^{2}$ or to observe if they ever coincided with those of the other instruments. My figures merely give the intervals in tenths of seconds which elapsed between successive

1 There is no reason to believe that the distribution of beats and accents corresponds with the number and position of accented and unaccented syllables of words understood.

2 The accented beats of the tawak are naturally longer, as a rule, than the unaccented beats. 
tawak-beats. But I am convinced by my experience on other occasions that the rhythm of the latter was completely independent of that of the rest of the orchestra.

\section{METHOD I. ${ }^{1}$}

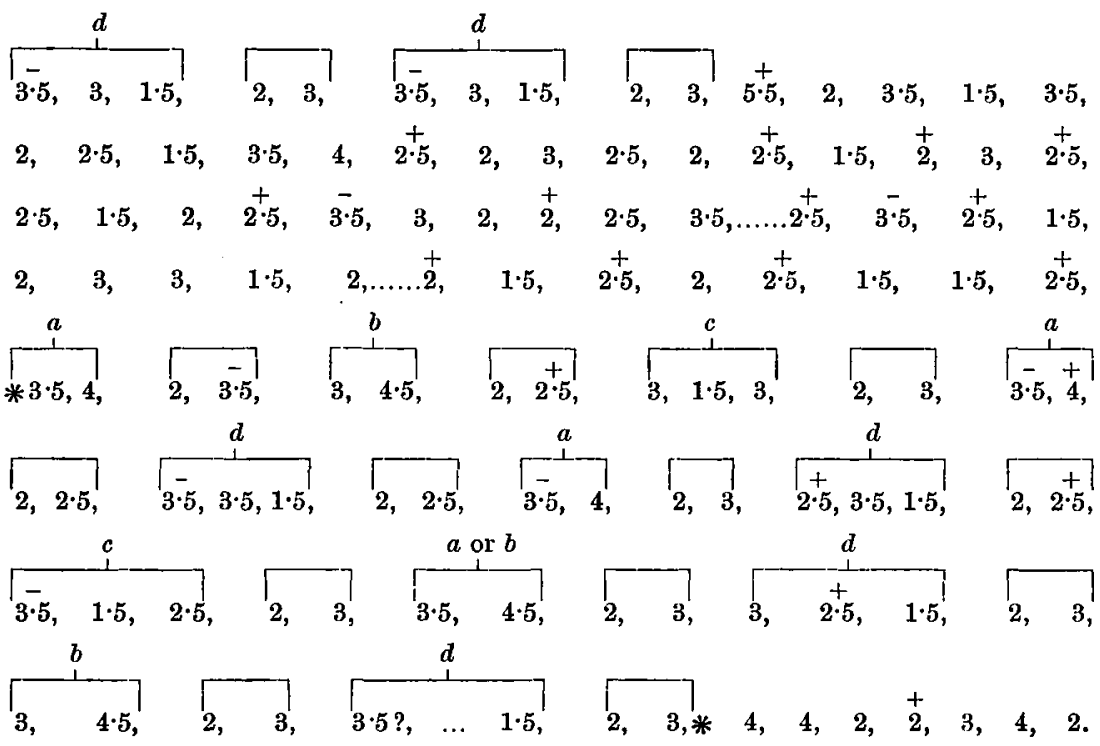

I was for a long time puzzled at the apparent lack of regularity in these figures. But I succeeded at last in systematizing that section which lies between the two asterisks. There can be no doubt that here the beats are grouped in two alternately recurring 'bars' which are of different lengths. The one comprises $7 \cdot 5$ units (i.e. tenths of seconds), the other 5 units. The beats within the latter bar are always two in number and always have the values 2 and 3 . Those within the former bar may be two or three in number, with the values (a) 3.5 and 4 , (b) 3 and 4.5, (c) 3, 1.5 and 3 or $(d) 3,3$ and 1.5 . The figures sometimes do not tally precisely with this plan, but the absolute value of such deviations is so small as to be negligible. In other words, then, if we represent one unit interval by the quaver" ${ }^{2}$, the various groups met with may be written thus :

1 Each figure represents the number of tenths of seconds between successive beats. The signs + or - over a figure indicate that its value is very slightly higher or lower than that recorded. A dotted line shows where the record is undecipherable. The brackets and letters are explained later.

2 The metronome-rate thus being, $\delta=150$. 


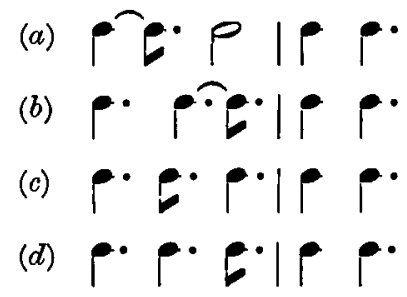

An alternation of such measures would of course fail to be appreciated by the European ear.

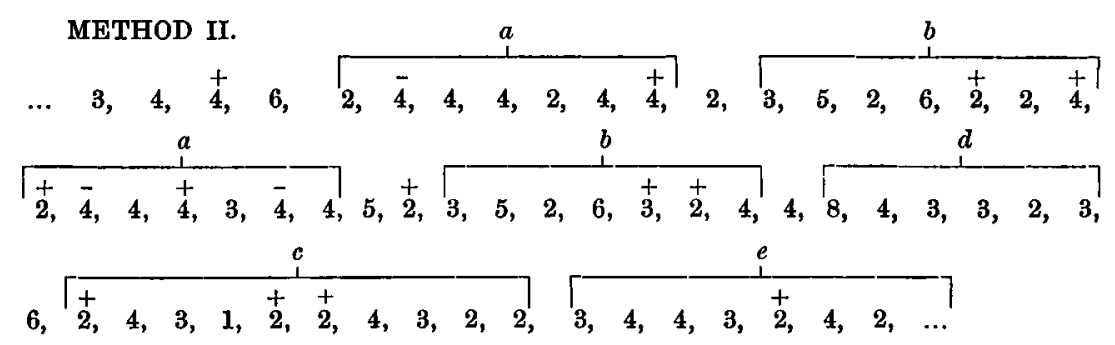

Here again we have evidence of the grouping together of measures of various duration so as to form longer periods $(a)$ and $(b)$ which are subsequently repeated. These periods or groups may be separated by one or more beats from one another.

Group (a) which is repeated may be represented thus:

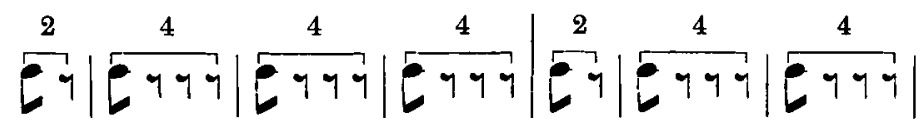

There is a change from a two-pulse to a four-pulse period.

Group $(b)$ which is also repeated may perhaps be represented:

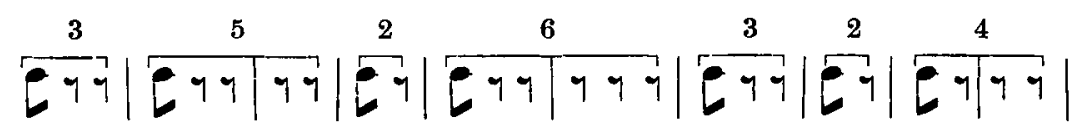

Group (c) contains the double group 24312. It may be written:

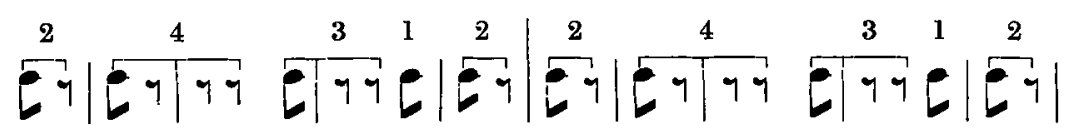

Alike in $(b)$ and $(c)$ we have alternating groups of two and threepulse periods, - a condition closely analogous to that subsequently described in American-Indian music (p. 404) and in Greek metre (p. 402). 
The sum of the intervals within group $(c)$ is approximately twentyfive units: this is likewise the value of each of the groups $(a)$ and $(b)$. Possibly groups $(d)$ and $(e)$ are also equivalent.

METHOD III.

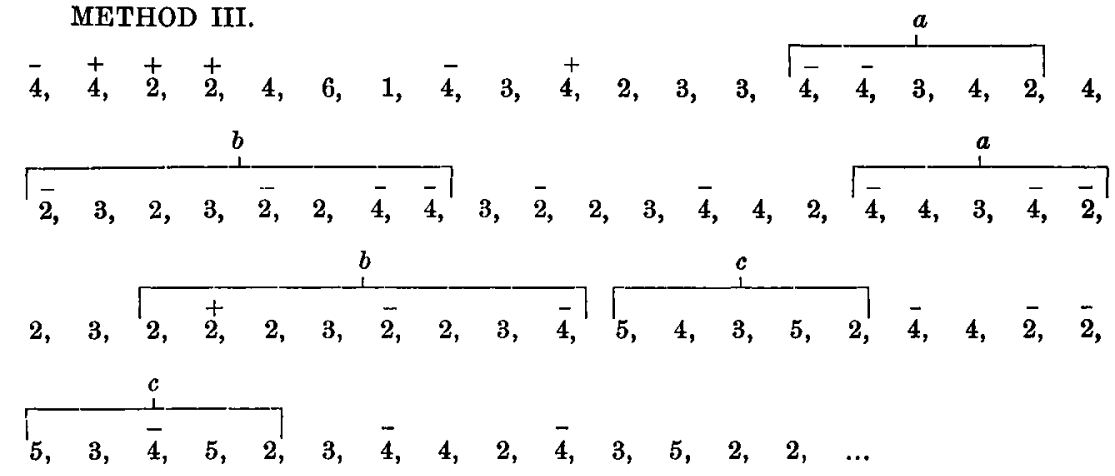

METHOD IV.

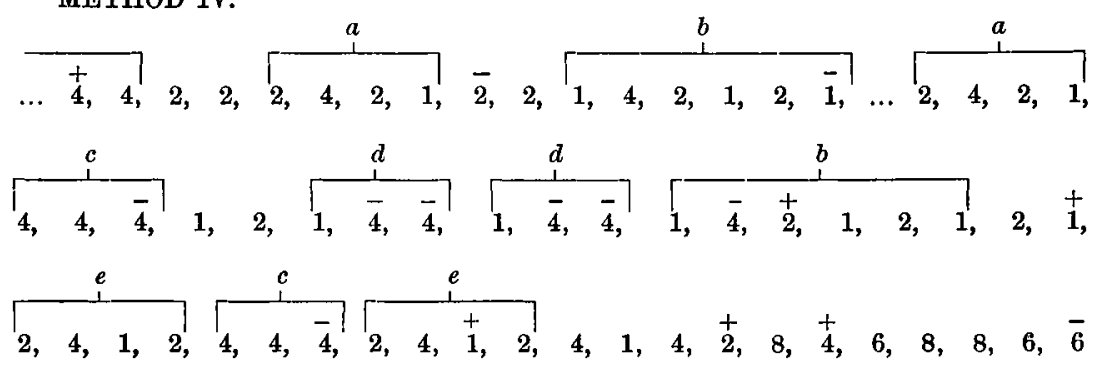

In these two methods, likewise, we find that beats, separated by intervals of different lengths, are gathered together into distinct groups, each group being divided by one or more beats from neighbouring groups. The third method closes with a succession of very rapid beats, the fourth with a succession of very slow beats.

In analysing the above records, it must be remembered that the performer was placed at a serious disadvantage while they were being made. There can be no doubt that he was disconcerted by the substitution of a Morse key for his accustomed instrument. To the consequent inaccuracies in his performance I am inclined to attribute in great part our inability to recognize methodical grouping in certain portions (especially at the beginning) of each record. 
II.

1. From a study of these records it is clear that the Malays of Sarawak are able to regard many successively different intervals of time as a coordinated whole which they recognize when repeated in the course of the performance. This faculty they carry to a degree which lies so far beyond the powers of civilized musicians, that the latter may reasonably be sceptical as to the possibility of its occurrence among less advanced peoples. I have, however, been fortunate in finding excellent corroborative evidence in ancient India. Day ${ }^{1}$ gives a table of some forty rhythmical periods or talas of early Indian Music. While their number and definition vary according to different authorities, each tâla had its own name and its mark of notation. I select four from Day's list:

\begin{tabular}{|c|c|c|}
\hline Name & Value in English notation & $\begin{array}{l}\text { Length of successive beats, } \\
\qquad=1\end{array}$ \\
\hline Tritéya .......... & 7 & 1,4 \\
\hline Simhallla ...... & & $2,1,1,1$ \\
\hline Simhavikrídita & & $2,2,6,2,4,6,2,6,4,6,8$ \\
\hline Simhânandanâ & & $\begin{array}{l}4,4,2,6,2,4,1,1,4,4,2, \\
\quad 6,2,6,4\end{array}$ \\
\hline
\end{tabular}

Day found it difficult to believe that such complex talas were ever "in very common use." But the analyses which we have just made of the methods of beating the Bornean tawak, leave no room for doubting that the early Indians, like the Malays, enjoyed the faculty of combining successive dissimilar periods and of regarding them as members of a complex unity.

The rhythms of the Ancient Greeks and of the Arabs ${ }^{2}$ were scarcely less complex. The fourth verse of the Greek alcaic metre, for example, ran thus:

$$
-\bullet \cup|-u v|-v|-v| \text {. }
$$

1 Captain C. R. Day, The Music and Musical Instruments of Southern India and the Deccan, London, 1891, p. 26.

2 R. G. Kiesewetter, Musik der Araber, Leipzig, 1842, S. 49-57. 
We may compare with it our interpretation (p. 400) of part of group (b) in the Malay method II.:

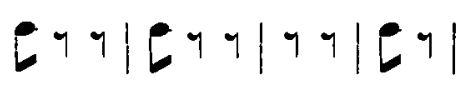

The pæonic and hemiolic rhythms of the Greeks are also remarkable? founded as they were on the ratio $3: 2$. Each of the five beats, according to some authorities, could be subdivided into five so that the whole foot migbt contain the ratios $15: 10$. It will be remembered that this is the precise ratio of the two parts $(7.5: 5)$ which repeatedly recur in method I. of the tawak-beating.

Doubtless these poetic metres were overlain by musical rhythms, just as in ruder form the beats of the Malay tawak accompanied the gong and drum orchestra. According to Headlam ${ }^{2}$ many of the complexities of Greek lyric metre may be attributed to an overlapping of rhythms one by another. He attributes their æsthetic value to an effect resembling counterpoint in music.

2. The complexity of the rhythms which may be employed by primitive peoples has been already noticed by some students of their music. Thus, Fillmore ${ }^{3}$ wrote of the Omahas, an American Indian people: "I know of no greater rhythmical difficulties anywhere in our modern music than these Omahas have completely at command in their every day music....... Rhythm is by far the most elaborately developed element of the Indian music, and in this respect civilized music has not surpassed it, at least in the point of combining dissimilar rhythms" (pp. 67-68). Their Hae-thu-ska dances, for example, "require the double drum beat, a strong pulse followed by a weak one. Against this many of the songs have three equal notes or their value" (p. 67). Thus the Song No. 19 (p. 93) contains the following bars:

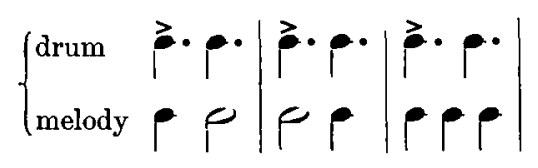

1 A. W. Ambros, Geschichte der Musik, Leipzig, 1880, Bd. ז. S. 432.

2 Journ. of Hellenic Studies, London, 1902, Vol. xxir. pp. 216, 219, 225.

3 "A study of Omaha Indian Music," by Alice C. Fleteher, Francis La Flesche, and John Comfort Fillmore, Archeological and Ethnological Papers of the Peabody Museum, Harvard Univ., Cambridge, Mass., U.S.A., June, 1893. 
Franz Boas ${ }^{1}$ transcribes (pp. 673, 687, 703) several songs of the Kwakiutl Indians of this type:

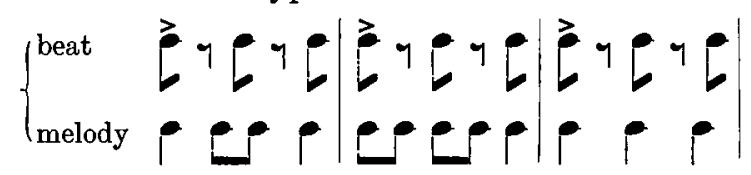

He remarks that "the beating is perfectly regular, five-eighths against three [fourths] of the tune" (p. 673). In other songs of the same collection different rhythms are opposed in a still more remarkable fashion.

Dittrich" observes that "the feeling for rhythm is very strongly developed among the Japanese. The most difficult syncopations...are performed with a precision that would astonish even a genuine musician in Europe" (p. 387). Stumpf ${ }^{3}$ also alludes to syncopation in Siamese, and Land ${ }^{4}$ in Javanese music.

3. Frequent change of rhythm has been likewise noted as a characteristic of certain primitive music. Thus, according to Abraham and von Hornbostel ${ }^{5}$, several Turkish songs contain bars of three beats interposed between bars of four beats. In their study of the music of India, the same observers ${ }^{6}$ write: "we find syncopation and change of rhythm so frequent that we are often unable to detect any constant primary rhythm at all, but are compelled to imagine a continual modification of measure" (p. 398). For example, Song No. 14 contains bars of 2, 3, 4,6, 8 and 9 crochets; Song No. 18 contains bars of 8, 9, 10 and 12 quavers. In Song No. 20 the drum-beats show regularly alternating groups of two-pulse and three-pulse periods:

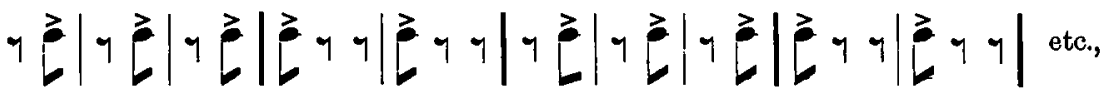

while the melody runs its course independently of this contrary rhythm, which forms a "kind of rhythmical counterpoint" overlying it.

1 “The Kwakiutl Indians," Smithsonian Reports. U.S. National Museum Reports for 1895, Washington, 1897.

2 "Beiträge zur Kenntniss der japanischen Musik," MIttheil. d. deutsch. Gesell. f. Natur- und Völkerkunde Ostasiens in Tokio, Tokio, $58^{\text {tes }}$ Heft, Jan. 1897.

3 “Tonsystem und Musik der Siamesen," Beitr. z. Akustik u. MIusikwissenschaft, Leipzig, 1901, Bd. r. Heft 3, S. 111.

4 "Die Tonkunst der Javanen," Vierteljahrsschr.f. Musikwissenschaft, 1889, Bd. v.

- "Phonographirte türkische Melodien," Zeitsch. $f$. Ethnologie, Berlin, 1904, Bd. xxxvi. S. $203-221$.

6 "Phonographirte indische Melodien," Sammelbände d. internat. Musik-Gesell., Leipzig, 1904, Jahrg. v. S. 348-401. 
Similar evidence is mentioned by some earlier writers upon the subject, who, moreover, emphasize the ability of the American Indians ${ }^{1}$ and Indians ${ }^{2}$ to perform five- and seven-pulse measures.

Describing the modern music of India, Day writes (loc. cit. p. 36), "The different degrees of time are called Tâlas, of which there are seven, each being subdivided into five 'jâtis' or kinds; so that there are in use no less than thirty five distinct measures. By the annexed table the various tâlas and their respective jâtis will be understood at a glance, the figures signifying the number of beats of equal duration made in a bar."

\begin{tabular}{|c||r|r|r|r|r|}
\hline \multirow{2}{*}{ Name of Tâla } & \multicolumn{5}{|c|}{ Name of Jâti } \\
\cline { 2 - 7 } & Chaturúshra & Tishra & Mishra & Cúndha & Sankírna \\
\hline Dhruva ........ & 4244 & 3233 & 7277 & 5255 & 9299 \\
Mátsya ........ & 424 & 323 & 727 & 525 & 929 \\
Rupaka ........ & 42 & 32 & 72 & 52 & 92 \\
Jiımpa ........ & 412 & 312 & 712 & 512 & 912 \\
Triputa ........ & 422 & 322 & 722 & 522 & 922 \\
Atatâla ........ & 4422 & 3322 & 7722 & 5522 & 9922 \\
Ekatâla ......... & 4 & 3 & 7 & 5 & 9 \\
\hline
\end{tabular}

III.

The rhythmical characteristics of the examples of primitive music which we have studied are three in number: a delight in change and in opposition of rhythm, and a demand that relatively long periods filled with measures of diverse length be apprehended as an organic whole or 'phrase.' To such an extreme have we found these features occasionally to be carried that their æsthetic effects may be neither appreciated nor reproducible by more advanced peoples.

Indeed among ourselves the progress of music has been by the elaboration of barmony rather than of rhythm. But just as the complexities of European harmony have developed from a basis of simple relation between the vibration-frequencies of simultaneously occurring

1 "Lieder der Bellakula Indianer," von C. Stumpf, Vierteljahrsschr. f. Musilwwissenschaft, 1886, Bd. Ir. S. 409.

2 Hindu Music from various Authors, compiled by [Rajah Sir] Sourindro Mohun Tagore, Calcutta, 1875, pp. 51, 261. 
tones, so those of primitive rhythm have developed from a basis of simple relation between the duration of successively occurring periods. The development of harmony and of rhythm alike invoke the psychological acts of analysis, synthesis and fusion.

While the later advances in choral singing in Europe required a more regular and a more frequent accent than was necessary in earlier stages of European culture, primitive music, unhampered by the demands of harmony and polyphony, has evolved complications of succession rather than of simultaneity,-complications of measure rather than of tone.

In the early mediæval music and among the existing folk-songs of many parts of Europe, curious irregularities or even defects of rhythm are met with. Within relatively modern times our composers have successfully obtained novel and striking effects by departures from the uniform and more conventional rhythms. Whether they will ever adopt such complex rhythms as are in use among certain primitive peoples, must depend on the gradual education of their audience and on the limiting value of the strain of attention which is compatible with æsthetic pleasure. 